\title{
The assessment of winter wheat agrocenoses adaptivity in the conditions of the submontane zone of the Central Caucasus
}

\author{
I.R. Manukyan ${ }^{1 *}$, E.S. Miroshnikova ${ }^{1}$, V.I. Gasiev ${ }^{1}$, T.S. Abieva ${ }^{1}$, N.L. Machneva ${ }^{2}$, A.S. Skamarokhova ${ }^{3} \&$ \\ D.A. Yurin ${ }^{3}$ \\ ${ }^{1}$ North Caucasus Research Institute of Mining and Predmont Agriculture, Vladikavkaz Scientific Center of the Russian Academy of Sciences, \\ Vladikavkaz, Russia \\ ${ }^{2}$ FSBEI of HE "Kuban State Agrarian University named after I.T. Trubilina ", Krasnodar, Russia \\ ${ }^{3}$ Federal State Budgetary Institution "Krasnodar Scientific Center for Zootechnics and Veterinary Medicine", Krasnodar, Russia \\ *Email: miririna.61@mail.ru
}

\section{ARTICLE HISTORY}

Received: 24 August 2020

Accepted: 06 October 2020

Published: 20 October 2020

\section{KEYWORDS}

Ontogenetic adaptability

Homeostaticity of the plants

Productivity

Ecological plasticity

Mixed varieties
ABSTRACT

The article presents the results of 3 years study on the adaptation of the properties of various winter wheat varieties to the conditions of the submontane zone of the Central Caucasus. The indicator of the ontogenetic adaptability was the homeostaticity of the plants. We have studied thirty winter wheat varieties according to the parameters of ecological plasticity, productivity and resistance to the destructive complex of diseases and pests like Fusarium head blight, brown and yellow rust, Septoria blight, tan spot etc. The yield of the mixed variety crops was $4.5 \mathrm{t} / \mathrm{ha}$; the increase was $9 \%$. In the crops of the triple mixture of the strong Veda and Delta varieties (25\%) with the valuable Batko variety $(50 \%)$, which differed in resistance to various diseases, the average yield of $52 \mathrm{cwt} / \mathrm{ha}$ was obtained with the protein content of $12 \%$, the gluten content of $28 \%$ and the flour strength of 320 a.u. The authors used the resistance of the precocious Kuma variety to the damage by the cereal leaf beetle as a protective screening crop along with the field perimeter. Such a screening crop of the stable variety prevents the colonization of the crops of the other less resistant varieties with pests. The genetic diversity of the variety creates the conditions for regulating and stabilizing the phytosanitary state of the crops and increasing their productivity. With this agrotechnical method, it becomes possible to regulate and stabilize the phytosanitary situation in the fields and to increase grain productivity and quality.

\section{Introduction}

The stability of any ecosystem is associated with the biological diversity and the complexity of the trophic relations between the organisms in it. There are natural and artificial ecosystems created by human activity, namely, agrocenoses. Agrocenoses differ from the natural ecosystems in high productivity, low diversity of living organisms and low environmental sustainability, since the cultivated species are extremely sensitive to pests and diseases and cannot compete for water, mineral nutrients and sunlight with the wild species $(1,2)$.

An important role in the efficient use of natural resources is played by ratio of different grain crops in the structure of the crop rotation. It is possible to increase the stability and productivity of the grain agrocenosis by building it based on choosing the adapted (resistant to bio- and abio-stressors) varieties of winter wheat and their placement on the crop rotation area (1, 3-5).

The "flexible" species and varietal structure of the winter crop areas in the adaptive crop production system became widely used. This structure is formed with regard to the ecological plasticity of the varieties, resistance to diseases and the phytosanitary situation in the region. The modern varietal policy developed by the leading scientists of the Krasnodar Lukyanenko Agricultural Research Institute (KNIISH) (3) suggests cultivating a wide range of the varieties that differ in a complex of the biological and economically valuable traits, their targeted use following the principle of the

(C) Manukyan et al (2020). This is an open-access article distributed under the terms of the Creative Commons Attribution License, which permits unrestricted use, distribution and reproduction in any medium, provided the original author and source are credited (https://creativecommons.org/licenses/by/4.0/).

To cite this article: Manukyan I R, Miroshnikova E S, Gasiev V I, Abieva T S, Machneva N L, Skamarokhova A S \& Yurin D A. The assessment of winter wheat agrocenoses adaptivity in the conditions of the submontane zone of the Central Caucasus. Plant Science Today. 2020;7(4):623-626. https://doi.org/10.14719/pst.2020.7.4.925 
"mosaic" distribution and limiting a variety share in the total crop area to not over $15 \%$, depending on its adaptive properties (11).

We aimed the research at increasing the environmental sustainability of the grain agrocenosis (with a specific species composition and specific relationships between components) being the main reserve for environmental safety and the growth of winter wheat productivity.

To achieve this goal, the peculiarities of the soilclimatic and biotic factors of the region were studied, and the adaptability of the winter wheat varieties to the cultivation conditions was comprehensively assessed. The methods of building a grain agrocenosis according to the principle of the mosaic of varieties and of mixed varieties that increase biological (genetic) diversity in crop rotation have been recommended.

\section{Materials and Methods}

The studies were conducted during 2010-2018. Over the years of the research in Krasnodar Lukyanenko Agricultural Research Institute (KNIISH), we had studied over 20 soft winter wheat varieties for example: Batko, Fisht, Kroshka, Veda, Leda, Pamyat, Grom, Fortuna, Vostorg, Alekseich, Ethnos, Yesaul etc. The phenological observations and accounting were made using the methods of state grade testing (6). For assessing the adaptive properties, the stability parameters and the ecological plasticity $\left(b_{i}\right)$, adopted the standard method $(4,7)$. The stress resistance (Ymin - Ymax) and the genetic flexibility ((Ymax + Ymin)/2) were also determined (8). The coefficient of variation was calculated (9). The homeostaticity (Hom) and the breeding value (Sc) were calculated according to another method (10). All varieties were studied using the combined analysis (9). Stability was assessed by means of the Spearman's nonparametric correlation analysis.

\section{Results and Discussion}

\section{The peculiarities of the winter wheat cultivation conditions in the submontane zone of the Central Caucasus}

It characterises the autumn period from September to November as arid, the autumn drought is observed almost every year. The winter period is warm with little snow. From the beginning of March, the reserves of productive moisture in the soil in the dry years may reach 11-18 mm, which is not enough for the plants, especially during the initiation of ear. In May - June, the amount of precipitation usually exceeds the norm by 135-150\%. In the region where $70 \%$ of the arable land is occupied by maize for grain, short crop rotation prevails (12).

\section{The main harmful complex of pests and diseases characteristic of the submontane zone of the Central Caucasus}

The varietal composition of phytophages on winter wheat is represented by over 20 insect species of following orders: Lepidoptera, Coleoptera, Diptera, Hemiptera, Thysanoptera, Homoptera etc. (13). The dominant pests on winter cereals in the early periods of vegetation were phytophagous bugs and the cereal leaf beetle [Oulema melanopus (L.)]. The maximum number of phytophagous bugs was noted during the periods of ear formation and flowering (12).

Over the years of the research, 38 species of phytopathogens were noted on winter wheat, including 31 species of fungi, six types of bacteria, and one type of virus. The harmful complex of diseases is represented by various pathogens, among which the most common are the pathogens of Fusarium head blight-Fusarium graminearum Schw, brown rust-Puccinia triticina R., yellow rustPuccinia striiformis West., tan spot or yellow leaf spot -Pyrenophora tritici-repentis Died and Septoria blight-Septoria tritici R. The spread of powdery mildew is reduced compared to previous years of the study. By the resistance to the diseases, in particular to Fusarium head blight, the varieties differ significantly from each other. Most varieties (40\%) are moderately susceptible to Fusarium head blight, and $23.3 \%$ are susceptible. The moderately resistant type included $36.7 \%$ of studied varieties, including Kuma, Deya, Yesaul, Starshina, Delta, Nota, Antonina etc. (Table 1).

\section{The adaptability of the winter wheat varieties}

We show the calculation of the adaptability parameters by productivity on the example of eight varieties (Table 2). The analysis of variance (AV) showed that the contribution to the total variability

Table 1. The immunological characteristic of the winter wheat varieties in terms of resistance to Fusarium head blight.

\begin{tabular}{|c|c|c|}
\hline $\begin{array}{c}\text { MR } \\
\text { Moderately } \\
\text { resistant }\end{array}$ & $\begin{array}{c}\text { MS } \\
\text { Moderately susceptible }\end{array}$ & $\begin{array}{c}\text { S } \\
\text { Susceptible }\end{array}$ \\
\hline $\begin{array}{l}\text { Kuma, Yesaul, } \\
\text { Starshina, Tanya, } \\
\text { Deya, Zimorodok, } \\
\text { Nota, Delta, } \\
\text { Moskvich, Don 107, } \\
\text { Antonina }\end{array}$ & $\begin{array}{l}\text { Batko, Fisht, Kroshka, } \\
\text { Veda, Leda, Pamyat, } \\
\text { Grom, Fortuna, Vostorg, } \\
\text { Alekseich, Ethnos, } \\
\text { Yesaul }\end{array}$ & $\begin{array}{l}\text { Pobeda 50, List 25, } \\
\text { Utrish, Bezostaya } \\
\text { 100, Zira, Lira, } \\
\text { Irishka }\end{array}$ \\
\hline
\end{tabular}

of productivity belonged to the genotypes of the studied varieties (the variety factor); their share was $50 \%$. The share of variability, caused by the influence of environmental conditions (the year factor), was $26.5 \%$. The share of the other factors was $23.5 \%$. The degree of the genotype reaction to changes in the environmental conditions or ecological plasticity, is well described by the regression coefficient $\left(b_{i}\right)$, which shows the plasticity of a variety and shows its ability to maintain its productivity upon the deterioration of the growing conditions $(14,15)$.

The varieties with $b_{i} \geq 1$ are especially valuable; they can increase their productivity upon improving the growing conditions. The homeostaticity reflects the variety's ability to maintain synthesis and accumulation of the plastic substances in various growing conditions. The higher this indicator is, the more stable the variety in various years (Table 3).

The Don 107 and Pamyat varieties showed low indicators of ecological plasticity $\left(b_{i}<1\right)$ of 0.9 and 0.8 
Table 2. The results of the analysis of variance by the parameters of the varieties' yield rate.

\begin{tabular}{|c|c|c|c|c|c|c|}
\hline \multirow{2}{*}{ The type of dispersion } & \multirow{2}{*}{$\begin{array}{c}\text { The sum of } \\
\text { squared } \\
\text { deviations }\end{array}$} & \multirow{2}{*}{$\begin{array}{c}\text { The number of } \\
\text { degrees of } \\
\text { freedom }\end{array}$} & \multirow{2}{*}{$\begin{array}{c}\text { The average } \\
\text { square }\end{array}$} & \multirow{2}{*}{$\begin{array}{l}\text { The share of the } \\
\text { factors' } \\
\text { contribution \% }\end{array}$} & \multicolumn{2}{|c|}{$\begin{array}{c}\text { The ratio of } \\
\text { variances (F) }\end{array}$} \\
\hline & & & & & actual & table \\
\hline Total & 0.68 & 32 & 0.021 & - & & \\
\hline The year factor $\mathrm{A}$ & 0.18 & 2 & 0.900 & 26.5 & 112.5 & 5.9 \\
\hline The variety factor B & 0.34 & 10 & 0.034 & 50.0 & 42.5 & 2.4 \\
\hline Residual & 0.16 & 20 & 0.008 & 23.5 & & \\
\hline
\end{tabular}

Table 3. The parameters of the winter wheat varieties' adaptability in the conditions of the submontane zone of the Central Caucasus.

\begin{tabular}{|c|c|c|c|c|c|}
\hline Variety & $Y \min -Y \max , t / h a$ & $(Y \max +Y \min ) / 2, t / h a$ & Average $x_{i}, t / h a$ & $\mathbf{b}_{\mathrm{i}}$ & Hom \\
\hline Don 107 & -0.58 & 3.74 & 3.66 & 0.9 & 339 \\
\hline Tanya & -0.57 & 4.16 & 4.23 & 2.1 & 577 \\
\hline Pamyat & -0.13 & 4.00 & 4.01 & 0.8 & 570 \\
\hline List 25 & -0.24 & 4.01 & 4.43 & 2.2 & 378 \\
\hline Kuma & -0.58 & 4.46 & 4.43 & 2.2 & 467 \\
\hline$\overline{\text { Veda }}$ & -0.69 & 4.26 & 4.13 & 2.3 & 437 \\
\hline$\overline{\text { Deya }}$ & -0.60 & 4.64 & 4.56 & 2.2 & 375 \\
\hline Batko & -0.48 & 4.59 & 4.60 & 1.6 & 384 \\
\hline
\end{tabular}

respectively. They showed moderate adaptation to the adverse conditions but could ensure stable yield in various conditions and with poor soil fertility. The conditions of the year had a significant effect on the productivity of the Tanya, Veda, Deya, List 25 and Kuma varieties $\left(b_{i}=2.1\right.$ to 2.3$)$ (Table 3$)$.

The Tanya variety, in which $b_{i}$ exceeded 1 (2.2), also featured a high homeostasis indicator (Hom = 577). This variety may be effectively cultivated using intensive technology. The Kuma and Veda varieties had similar $b_{i}$ and Hom indicators and positively responded to improving the growing conditions and high soil fertility. The Deya and Batko varieties had high yields of 4.56 and 4.60 t/ha and similar homeostaticity indicators of 378 and 384 . The ecological plasticity indicator $\left(\mathrm{b}_{\mathrm{i}}\right)$ in the Batko variety was 1.6, which showed more stable productivity and responsiveness to improving the growing conditions.

Spearman's correlation coefficient for the studied indicators was positive.

\section{Conclusion}

Thus, the yield of the mixed variety crops was 4.5 t/ha; the increase was $9 \%$. In the crops of the triple mixture of the strong Veda and Delta varieties (25\%) with the valuable Batko variety (50\%), which differed in resistance to various diseases, the average yield of $52 \mathrm{cwt} / \mathrm{ha}$ was obtained with the protein content of $12 \%$, the gluten content of $28 \%$ and the flour strength of 320 a.u. The authors used the resistance of the precocious Kuma variety to the damage by the cereal leaf beetle as a protective screening crop along the field perimeter. Such a screening crop of the stable variety prevents the colonisation of the crops of the other less resistant varieties with pests.

The genetic diversity of the varieties creates the conditions for regulating and stabilising the phytosanitary state of the crops and increasing their productivity. With this agrotechnical method, it becomes possible to regulate and stabilise the phytosanitary situation in the fields and to increase grain productivity and quality.

\section{Acknowledgements}

The authors express their gratitude to the employees of the Laboratory of Mycology and Phytopathology FSBSI VIZR.

\section{Authors' contributions}

All authors contributed equally. All authors read and approved the final manuscript.

\section{Conflict of interests}

Authors do not have any conflict of interests to declare.

\section{References}

1. Manukyan IR, Basieva MA, Abiyev VB, Yurina NA, Gneush AN, Ashinov YN. The sources of economically valuable traits of winter wheat varieties in the conditions of the forest-steppe zone of the Central Caucasus. Annals of Agri-Bio Research. 2019;24(2):242-45

2. Manukyan IR, Basieva MA, Gneush AN, Arutyunova GY, Udychak MM, Yurin DA. Complex evaluation of productivity and environmental plasticity of the winter wheat breeding material for the conditions of the submontane zone of Central Caucasus. Management, Economic Engineering in Agriculture and Rural Development. 2019;19(4):159-65

3. Romanenko AA, Bespalova LA, Kudryashov NI, Ablova IB. Novaya sortovaya politika i sortovaya agrotekhnika ozimoi pshenitsy. The new varietal policy and varietal winter wheat agricultural technology. Krasnodar; 2005

4. Eberhart SG, Russell WG. Stability parameters for comparing varieties. Crop Sci. 1966;6(1):36-40

5. Yurina NA, Koshchaev AG, Osepchuk DV, Maksim EA, Danilova AA, Shumeiko DV. Artificial ecological system - Hydroponics: The wheat grains germination rate. International Journal of Engineering and Advanced Technology. 2019;9(1):4957-60. https://doi.org/ 10.35940/ijeat.A2109.109119

6. Fedin MA (ed.). Metodika gosudarstvennogo sortoispytaniya selskokhozyaistvennykh kultur [The methodology of crops state variety testing]. Moscow: Kolos; 1985

7. Pakudin VZ, Lopatina LM. Otsenka ekologicheskoi plastichnosti i stabilnosti sortov selskokhozyaistvennykh kultur [Assessment of the environmental plasticity and 
stability of the crop varieties]. Agricultural biology. 1984;4:10913

8. Rosielle AA, Hamblin J. Theoretical aspects of selection for yield in stress and non-stress environments. Crop Sci. 1981;21(6):943-46

9. Dospekhov BA. Metodika polevogo opyta [The methods of field experiment]. Moscow: Agropromizdat; 1985

10. Khangildin VV. Parametry otsenki gomeostatichnosti sortov selektsionnykh linii $\mathrm{v}$ ispytaniyakh kolosovykh kultur [The parameters for assessing the homeostaticity of the varieties of breeding lines in cereal testing]. Scientific and Technical Bulletin of the All-Union Genetic Selection Institute. 1986;2(60):36-41

11. Bekuzarova SA, Manukyan IR, Abiyev VB. RF patent 2354096, IPC A01C 1/00 (2006.01) Sposob sozdaniya iskusstvennogo infektsionnogo fona dlya ozimoi pshenitsy [The Method of Creating Artificial Infectious Background for Winter Wheat]. Published on 10.05.2009. Bulletin No. 13
12. Manukyan IR, Abiyev TS, Abaev AA, Abiyev VB. Paten 2555416, IPC A01G 13/00 (2006.01) Sposob borby s pyavitsei obyknovennoi $\mathrm{v}$ posevakh ozimoi pshenitsy [A method for fighting cereal leaf beetle in the winter wheat crops] Published on 07.10.2015. Bulletin No. 19

13. Manukyan IR. Fitopatogeny ozimoi pshenitsy v Severnoi Osetii. The pathogens of winter wheat in North Ossetia. Protection and quarantine of plants. 2003;3:32-33

14. Manukyan IR, Basieva MA, Miroshnikova ES, Abiyev VB. Otsenka ekologicheskoi plastichnosti sortov ozimoi pshenitsy v usloviyakh predgornoi zony Tsentralnogo Kavkaza [Assessment of the environmental plasticity of winter wheat varieties in the submontane zone of the Central Caucasus]. The Agrarian Bulletin of the Urals. 2019;4(183):20-26

15. Manukyan IR, Basieva MA, Miroshnikova ES, Abiev VB. Usage of a new plant productivity index for evaluation of winter wheat breeding material. Volga Region Farmland. 2019;2(2):3439. https://doi.org/10.26177/VRF.2019.2.2.009 